\title{
SALIVARY CORTISOL AND METABOLIC SYNDROME COMPONENT'S ASSOCIATION
}

\author{
Associação do cortisol salivar com os componentes da síndrome metabólica \\ Grasiane Izidorio GARBELLOTTO' ${ }^{1}$,Fernanda Jardim REIS' ${ }^{1}$, Ana Maria Pandolfo FEOLI ${ }^{1}$, \\ Carla Haas PIOVESAN ${ }^{1}$, Andréia da Silva GUSTAVO', Margareth da Silva OLIVEIRA ${ }^{1}$,Fabrício Edler MACAGNAN ${ }^{1}$, \\ Carlos Alexandre Sanchez FERREIRA'2, Moisés Evandro BAUER ${ }^{2}$, Cácio Ricardo WIETZYCOSKI ${ }^{1}$
}

How to cite this article: Garbellotto Gl, Reis FJ, Feoli AMP, Piovesan CH, Gustavo AS, Oliveira MS, Macagnan FE, Ferreira CAS, Bauer ME, Wietzycoski CR. Salivary cortisol and metabolic syndrome component's association. ABCD Arq Bras Cir Dig. 2018;31(1):e1351. DOI: /10.1590/0102672020180001e1351

From the ${ }^{1}$ Faculdade de Enfermagem, Nutrição e Fisioterapia, Pontifícia Universidade Católica do Rio Grande do Sul, Porto Alegre, RS, ${ }^{2}$ Programa de Pós-Graduação em Biologia Celular e Molecular (PPGBCM) da Faculdade de Biociências da PUCRS ('Faculty of Nursing Nutrition and Physiotherapy, Pontifícia Universidade Católica do Rio Grande do Sul, ${ }^{2}$ Post-graduate Programa in Molecular and Cellular Biology, Biosciences Faculty, PUCRS), Porto Alegre, RS, Brazil.

HEADINGS - Obesity. Metabolic syndrome. Hydrocortisone.

\section{Correspondência:}

Grasiane Izidorio Garbellotto

Email: grasigar@hotmail.com

Financial source: none

Conflict of interest none

Received for publication: 14/11/2017

Accepted for publication: 23/01/2018

DESCRITORES - Obesidade. Síndrome metabólica. Hidrocortisona.
ABSTRACT- Background: Actually the lifestyle exposes the population to several risk factors related to alimentary habits and less physical activity that contributes to chronic diseases appearance worldwide. Aim: To analyze the association between salivary cortisol and the components of metabolic syndrome. Methods: This is a cross-sectional study. As part of it 28 individuals aged 30-59 years presenting three or more of the following findings: CA: $\geq 88$ $\mathrm{cm}$ for women and $\geq 102 \mathrm{~cm}$ for men; SBP>130 mmHg and DBP> $85 \mathrm{mmHg} ; \mathrm{GL}>100 \mathrm{mg} / \mathrm{dl}$; $\mathrm{TG}>150 \mathrm{mg} / \mathrm{dl} ; \mathrm{HDL}<40 \mathrm{mg} / \mathrm{dl}$ for men and $<50 \mathrm{mg} / \mathrm{dl}$ for women. Was performed analysis of salivary cortisol (by radioimmunoassay) from 25 salivary samples collected throughout the day, for evaluating changes in the circadian rhythm of this hormone (8AM, noon and 8PM). Results: 28 evaluated individuals had a mean age of $51.9 \pm 7.5$ years, mostly women (64.3\%) and a mean of BMI $33.6 \pm 3.2 \mathrm{~kg} / \mathrm{m}^{2}$. The cortisol level from the $8 A M$ averaged $18.7 \pm 4.8 \mathrm{ng} / \mathrm{dlL}$. Individuals with FPG $>110 \mathrm{mg} / \mathrm{dl}$, have significantly lower average levels of cortisol than ones with FPG $<110(12.8 \pm 5,2$ vs. $17.3 \pm 4.2)$. Significant correlations were HOMA vs. WC $(r=0,465$; $p<0,005)$ and TG $(r=0,473 ; p<0,005)$, WC vs. FG $(r=0,446 ; p<0,005)$ and $B M I(r=0,730 ; p<0.0001)$; TG vs. HDL $(r=0,441 p<0,005)$ and FG $(r=0,440 ; p<0,005)$. Conclusion: Morning salivary cortisol in subjects with chronically elevated blood glucose can represent a downregulation of the hypothalamic-pituitary adrenal axis. This is an important finding not yet well investigated.

RESUMO - Racional: Atualmente o estilo de vida expõe a população a diversos fatores de risco relacionados a hábitos alimentares e à inatividade física, contribuindo para o surgimento de doenças crônicas. Objetivo: Analisar a associação entre o cortisol salivar e os componentes da síndrome metabólica. Métodos: Estudo transversal com 28 indivíduos, idade entre 30 e 59 anos apresentando três ou mais dos seguintes achados: circunferência abdominal $\geq 88 \mathrm{~cm}$ (mulheres) e $\geq 102 \mathrm{~cm}$ (homens); pressão arterial sistólica $>130 \mathrm{mmHg}$ e pressão arterial diastólica $>85$ $\mathrm{mmHg}$; glicemia $>100 \mathrm{mg} / \mathrm{dl}$; triglicerídeo $>150 \mathrm{mg} / \mathrm{dl}$; lipoproteína de alta densidade <40 mg/ $\mathrm{dl}$ (homens) e $<50 \mathrm{mg} / \mathrm{dl}$ (mulheres). Foram realizadas coletas do cortisol salivar nos seguintes horários $8 \mathrm{~h}, 12 \mathrm{~h}$ e $20 \mathrm{~h}$ e analisadas por radioimunoensaio. Resultados: A média de idade foi $51,9 \pm 7,5$ anos, $64,3 \%$ eram mulheres e a média do índice de massa corporal foi $33,6 \pm 3,2 \mathrm{~kg} /$ $\mathrm{m}^{2}$. O nível de cortisol salivar às $8 \mathrm{~h}$ teve média de $18,7 \pm 4,8 \mathrm{ng} / \mathrm{dl}$. Os indivíduos com glicemia de jejum $>110 \mathrm{mg} / \mathrm{dl}$, apresentaram níveis médios de cortisol significativamente menores que os com glicemia de jejum $<110 \mathrm{mg} / \mathrm{dl}(12,8 \pm 5,2$ vs. $17,3 \pm 4,2)$. As correlações significativas foram HOMA vs. circunferência abdominal $(r=0,465 ; p<0,005)$ e triglicerídeos $(r=0,473 ; p<0,005)$, circunferência abdominal vs. glicemia de jejum $(r=0,446 ; p<0,005)$ e índice de massa corporal $(r=0,730 ; p<0,0001)$, triglicerídeos vs. lipoproteína de alta densidade $(r=0,441 p<0,005)$ e glicemia de jejum $(r=0,440 ; p<0,005)$. Conclusão: $O$ cortisol salivar pela manhã, em indivíduos com glicemia cronicamente elevada, pode representar uma contraregulação do eixo hipotálamohipófise-adrenal, sendo achado importante e pouco investigado. (cc) BY This is an open-acces article distributed under the terms of the Creative Commons Attribution License.

\section{INTRODUCTION}

$T$ he current lifestyle exposes the population to several risk factors related to eating habits and lack of physical activity, contributing to the emergence of chronic diseases. Among these, cardiovascular, diabetes and obesity have become common causes of premature death ${ }^{18}$. Cardiovascular disease is the final event of several systemic alterations caused by other diseases such as hypertension, obesity, diabetes and hypercholesterolemia, which make up the so-called metabolic syndrome (MS), ${ }^{9,17}$. It is a complex set of cardiovascular risk factors, related to abdominal fat and insulin resistance, with high cardiovascular morbidity and mortality $9,17$.

According to The Third Report of the National Cholesterol Education Program - NCEPATP III15, diagnosis of MS is necessary to alter three of the five risk factors: abdominal obesity; abdominal circumference $\leq 102 \mathrm{~cm}$ (men) or $\leq 88 \mathrm{~cm}$ (women); triglycerides (TGL) $\geq 150 \mathrm{mg} /$ $\mathrm{dl}_{;} \mathrm{HDL}<40 \mathrm{mg} / \mathrm{dl}$ (men) or $<50 \mathrm{mg} / \mathrm{dll}$ (women); systolic blood pressure $\geq 130 / 85 \mathrm{mmHg}$ and fasting glycemia $\geq 100 \mathrm{mg} / \mathrm{dl}$, regardless of the presence of diabetes ${ }^{16,22}$. 
Another important metabolic marker is salivary cortisol, which serves as a barometer of stress ${ }^{27}$. It is synthesized from cholesterol and its production is stimulated by the adrenocorticotropic hormone (ACTH) which is regulated by the corticotropin releasing factor and excreted in urine, blood plasma and saliva. The action of cortisol affects several physiological systems such as immunefunction, glucose regulation, vascular tone, and bone metabolism. Its production has circadian rhythm that depends on $\mathrm{ACTH}$, with maximum levels in the morning decreasing throughout the day. ACTH and cortisol are secreted independently of the circadian rhythm as a reaction to physical and psychological stress ${ }^{27}$. In individuals exposed to constant chronic stressors, excess of cortisol is very harmful to health ${ }^{11}$.

The relationship between salivary cortisol and SM components evidences important stress response markers of the systemic inflammatory process associated with MS and its components.

The present study aims to demonstrate the results of the association between salivary cortisol and the components of MS.

\section{METHODS}

All selected participants signed the Informed Consent Form and individually received information about the study procedures. The confidentiality and confidentiality requirements of the information collected were complied with in accordance with Resolution No. 466/2012, which establishes the guidelines for human research. The project was approved by the ethics committee of the institution, under number: 10/05153. The main study was registered in the Brazilian Registry of Clinical Trials, ReBEC, under number: RBR-9wz5fc. The authors committed themselves to maintaining the confidentiality of the data.

This is a cross-sectional study based on secondary data extracted from the study on the effects of different lifestyle modification interventions on physical, metabolic and behavioral aspects involved in the metabolic syndrome through the MERC (Research Modification Style Group of Life and Cardiovascular Risk of Catholic University, RS, Brazil). From this study, 28 genderindependent individuals, aged 30-59 years, were analyzed. As an inclusion criterion, they had to present three or more of the following findings that characterize $\mathrm{SM}^{7}$ : abdominal circumference of $\geq 88 \mathrm{~cm}$ for women and $\geq 102 \mathrm{~cm}$ for men; systolic blood pressure $>130 \mathrm{mmHg}$ and diastolic $>85 \mathrm{mmHg}$; fasting glucose $>100 \mathrm{mg} / \mathrm{dl}$; triglycerides $>150 \mathrm{mg} / \mathrm{dl}$; HDL cholesterol $<40 \mathrm{mg} / \mathrm{dl}$ for men and $<50 \mathrm{mg} / \mathrm{dl}$ for women. Those who did not present all the necessary records in the main study database were excluded.

The assessment included the measurement of body weight, height and waist circumference. The body weight was verified by means of a scale with capacity for $160 \mathrm{~kg}$, duly calibrated, with the patient barefoot and with the least possible clothing. A vertical anthropometer was used to measure height. Abdominal circumference was assessed through the abdominal perimeter $(\mathrm{cm})$, measured at the site of maximum extension of the abdominal region ${ }^{12}$. The instrument used was an inelastic millimeter tape measuring $180 \mathrm{~cm}$ in length.

The values of systolic and diastolic blood pressure were measured according to the recommendations of $\mathrm{V}$ Brazilian Guideline for Hypertension ${ }^{24}$.

For blood collection, volunteers were previously instructed to fast for 10-12 $\mathrm{h}$. The collection of saliva was performed by the volunteer for later delivery to the research group. The evaluation of salivary cortisol was measured from samples collected throughout the day to evaluate changes in the circadian rhythm of this hormone, being $8 \mathrm{~h}$ (C8), at noon (C12) and at $20 \mathrm{~h} \mathrm{(C20).} \mathrm{All}$ collections were done before meals. They were used small rolls of cotton, previously prepared and sterilized for individual use. As for the method of collection the participant was advised to put the cotton roll under the tongue and leave for 3 min until it became saturated. Then remove the cotton and put it inside a $5 \mathrm{ml}$ syringe, without the plunger. After replacing the plunger in the syringe, they were oriented to press the cotton, collecting the saliva in a plastic tube properly identified with the study number, name and time of collection. The minimum volume of saliva collected for each hour was $0.5 \mathrm{ml}$. The samples were centrifuged for $5 \mathrm{~min}$ at $1000 \mathrm{rpm}$ and kept in a freezer $\left(-20^{\circ}\right.$ C) until analysis, performed by radio immunoassay with a high sensitivity of $0.09 \mathrm{ng} / \mathrm{ml}$ (DBC - Diagnostics Biochem Canada) ${ }^{3,10}$.

The blood biochemical markers analyzed were: lipid profile $(\mathrm{HDL}-\mathrm{C}$, total cholesterol (CT), triglycerides (TGC) whereas the determination of $L D L-c$ was performed indirectly $-L D L-C=(T G C / 5$ $+\mathrm{HDL}$ )/CT), glycemic profile (fasting glucose, fasting insulin and HOMA). For the analysis of biochemical markers, $10 \mathrm{ml}$ of blood were collected from each participant before and after the intervention, totaling $20 \mathrm{ml}$. Serum and plasma aliquots were separated for freezer storage at $-80^{\circ} \mathrm{C}$.

The IMC ${ }^{2}$ was calculated according to the World Health Organization's recommendation ${ }^{8}$ for nutritional status evaluation. The cutoff points for the classification of the individuals regarding BMI $\left(\mathrm{kg} / \mathrm{m}^{2}\right)$ were: normal $25 \mathrm{~kg} / \mathrm{m}^{2}$; overweight from 25-29.99 $\mathrm{kg} / \mathrm{m}^{2}$; obese $\geq 30 \mathrm{~kg} / \mathrm{m}^{2}$.

\section{Statistical analysis}

The Kolmogorov-Smirnov test was used to verify the normal distribution of the continuous data. The data were presented quantitatively (mean \pm standard deviation). To determine the relationship between continuous variables, the Pearson and Chi-square correlation test were used to measure the association between categorical/dichotomous variables. Student's T test was used to evaluate the difference between means. The level of significance was set at $p=0.05$ (bi-flow). For the analysis of the data the SPSS statistical package, version 22.0.0.0 was used.

\section{RESULTS}

We evaluated 28 individuals with MS, with a mean age of $51.9 \pm 7.5$ years; The majority were female $(64.3 \%)$ with an average BMI of $33.66 \pm 3.27 \mathrm{~kg} / \mathrm{m}^{2}$.

The $8 \mathrm{~h}$ salivary cortisol level had a mean of $16.70 \pm 4.87$ $\mathrm{ng} / \mathrm{ml}$; in the $12 \mathrm{~h}$ it was of $10.19 \pm 4.23 \mathrm{ng} / \mathrm{ml}$; and in $20 \mathrm{~h}$ of $4.74 \pm 2.30 \mathrm{ng} / \mathrm{ml}$. The cortisol drop throughout the day can be analyzed in Figure 1 . The reference value of the $8 \mathrm{~h}$ salivary cortisol used was $13.5-23.5 \mathrm{ng} / \mathrm{ml}$.

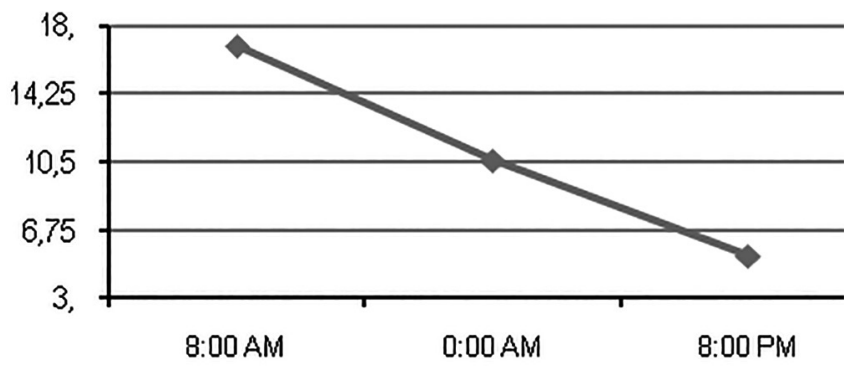

FIGURE 1 - Salivary cortisol levels ( $\mathrm{ng} / \mathrm{dl}$ ) in the $24 \mathrm{~h}$ period

The data results of the patients and variables studied can be seen in Table 1.

TABLE 1 - Characteristics of the sample

\begin{tabular}{|l|c|}
\hline \multicolumn{1}{c}{ Variables } & Mean $\pm \mathrm{SD}(\mathrm{n}=28)$ \\
\hline Age & $51.86 \pm 7.46$ \\
\hline Weight $(\mathrm{kg})$ & $91.72 \pm 12.34$ \\
\hline Body mass index $\left(\mathrm{kg} / \mathrm{m}^{2}\right)$ & $33.65 \pm 3.27$ \\
\hline Abdominal circumference $(\mathrm{cm})$ & $109.04 \pm 8.39$ \\
\hline Triglycerides $(\mathrm{mg} / \mathrm{dl})$ & $196.86 \pm 94.71$ \\
\hline High density lipoprotein - HDL $(\mathrm{mg} / \mathrm{dl})$ & $47.29 \pm 11.73$ \\
\hline Glucose $(\mathrm{mg} / \mathrm{dl})$ & $107.57 \pm 36.42$ \\
\hline Systolic blood pressure $(\mathrm{mmHg})$ & $133.68 \pm 16.06$ \\
\hline Diastolic blood pressure $(\mathrm{mmHg})$ & $91.36 \pm 13.05$ \\
\hline
\end{tabular}


The results regarding the correlation between salivary cortisol and the components of SM can be seen in Table 2 .

TABLE 2 - Correlation between salivary cortisol and components of metabolic syndrome

\begin{tabular}{|c|c|c|c|c|c|c|}
\hline \multirow{3}{*}{ Variables } & \multicolumn{6}{|c|}{ Salivary cortisol } \\
\hline & \multicolumn{2}{|c|}{$8 \mathrm{AM}$} & \multicolumn{2}{|c|}{ Noon } & \multicolumn{2}{|c|}{$8 \mathrm{PM}$} \\
\hline & $r$ & $p^{*}$ & $r$ & $p^{*}$ & $r$ & $p^{*}$ \\
\hline $\begin{array}{l}\text { Abdominal } \\
\text { circumference }\end{array}$ & -0.133 & 0.499 & -0.097 & 0.624 & 0.037 & 0.852 \\
\hline Systolic blood pressure & 0.108 & 0.583 & -0.140 & 0.478 & -0.186 & 0.344 \\
\hline Diastolic blood pressure & 0.000 & 0.997 & -0.181 & 0.356 & -0.264 & 0.174 \\
\hline $\begin{array}{l}\text { High density lipoprotein } \\
\text { - HDL }\end{array}$ & -0.191 & 0.331 & -0.090 & 0.647 & -0.224 & 0.252 \\
\hline Triglycerides & 0.264 & 0.175 & 0.054 & 0.786 & 0.006 & 0.997 \\
\hline Glucose & 0.052 & 0.792 & -0.203 & 0.301 & -0.197 & 0.314 \\
\hline Body mass index & -0.117 & 0.552 & -0.043 & 0.829 & 0.048 & 0.808 \\
\hline
\end{tabular}

Figure 2 shows the division of patients regarding the presence or absence of each component of MS; in this way, individuals with fasting glycemia $>110 \mathrm{mg} / \mathrm{dl}$ had significantly lower mean cortisol levels than those with fasting glycemia $<110 \mathrm{mg} / \mathrm{dl}$.

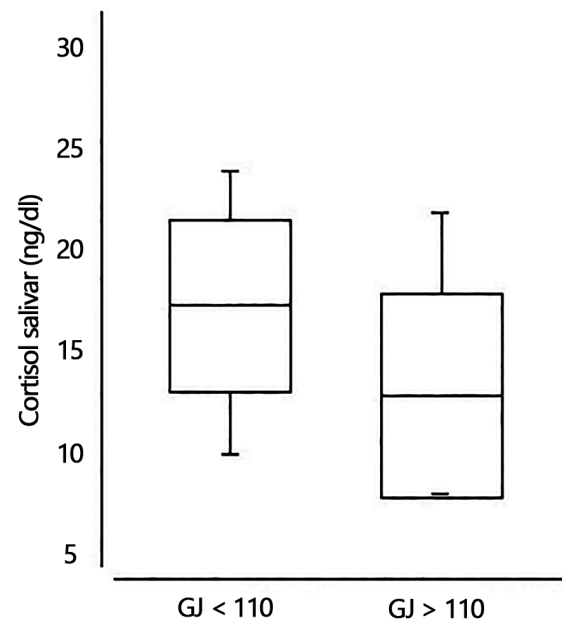

GJ=fasting glycemia

FIGURE 2 - Relationship of morning cortisol to fasting glycemia (Boxplot chart showing mean $\pm S D, p<0.05$ )

Insulin and HOMA measurements were available only in a subset of the study $(n=24)$. Table 3 shows the various variables and correlations between the components of SM, HOMA and morning salivary cortisol.

TABLE 3 - Correlation between the components of Metabolic Syndrome and Homestatic Model Assessment (HOMA)

\begin{tabular}{|lccc|}
\hline \multicolumn{1}{c}{ HOMA } & Total sample & $\mathrm{r}$ & $\mathrm{p}$ \\
\hline Cortisol & 24 & -0.049 & 0.818 \\
\hline Abdominal circumference & 24 & 0.465 & 0.022 \\
\hline Triglycerides & 24 & 0.473 & 0.019 \\
\hline Insulin & 24 & 0910 & $<0.001$ \\
\hline Fasting glycemia & 24 & 0.678 & $<0.001$ \\
\hline Abdominal circumference & Total sample & $\mathrm{r}$ & $\mathrm{p}$ \\
\hline Fasting glycemia & 28 & 0.446 & 0.017 \\
\hline Diastolic blood pressure & 28 & 0.375 & 0.050 \\
\hline Body mass index & 28 & 0.730 & $<0.001$ \\
\hline Triglycerides & Total sample & $\mathrm{r}$ & $\mathrm{p}$ \\
\hline High density lipoprotein - HDL & 28 & 0.441 & 0.019 \\
\hline Fasting glycemia & 28 & 0.440 & 0.019
\end{tabular}

When comparing the components of MS with salivary cortisol levels at 8AM, noon and 20PM, there is an important relationship between fasting glycemia and salivary cortisol. Individuals with fasting glycemia $>110 \mathrm{mg} / \mathrm{dl}$ have significantly lower salivary cortisol levels than those with glycemia $<110$ $\mathrm{mg} / \mathrm{dl}^{2}$.

Currently, the relation of the hypothalamic-pituitaryadrenal axis and alterations in glucose metabolism has been the subject of clinical studies $5,6,14,20,21,25$. A review of the recent literature has evaluated six studies that correlated morning cortisol with glucose; of these, only three demonstrated a positive association. Significantly higher levels of salivary cortisol at $10 \mathrm{~h}$ and dexamethasone-stimulated cortisol were found in subjects with type 2 diabetes mellitus when compared to the normoglycemic individuals. Salivary cortisol at $10 \mathrm{~h}$ correlated significantly with fasting glycemia and glycated hemoglobin. This study also demonstrated that diabetic subjects had a higher level of stress and stress response than non-diabetics, as measured by standard questionnaires. It is noteworthy that this study compared individuals with normal glycemic disorders with diabetics of recent diagnosis, and it can be inferred that the situation of significant stress due to the recent diagnosis of diabetes may have led to the increase of cortisol as a reaction to stress and not as a result of high blood glucose ${ }^{23}$.

Considering the results found in this study it can be inferred that the result of the lower salivary cortisol in subjects with fasting glycemia $>110 \mathrm{mg} / \mathrm{dl}$ observed in this study may be a paradoxical effect. This paradox could be explained by the fact that individuals presented chronic high fasting glycemia, and the acute stress period has already been overcome, and there is a possibility of downregulation of cortisol levels due to chronically high glycemia. That is, elevated insulin resistance, increased glycemia, and chronic oxidative stress counteract the adrenal pituitary hypothalamus axis in order to decrease morning cortisol levels in an attempt to return to metabolic homeostasis.

$\mathrm{SM}$ is a cluster of metabolic abnormalities that increases the risk of type 2 diabetes mellitus and cardiovascular disease, which can be defined as a state of metabolic homeostasis disorder characterized by a combination of central obesity, insulin resistance, dyslipidemia and hypertension ${ }^{19}$.

Salivary cortisol is an important marker of chronic stress and one of several stressors that can lead to changes in the hypothalamus adrenal pituitary axis, with alteration of the metabolic homeostasis of the organism and consequently to the metabolic disorders mentioned above $\mathrm{e}^{1,5,23}$. There is strong evidence to support the hypothesis that glucocorticoids released in response to chronic stress induce accumulation of visceral fat that, when present in some conditions, such as excessive energy intake, low physical activity and poor quality of food, will trigger the mechanism development of $\mathrm{SM}^{19}$.

Although previous studies have clearly demonstrated the usefulness of salivary cortisol to assess the rate and activity of the hypothalamic pituitary adrenal axis and also for the diagnosis of hypercortisolism ${ }^{13}$, its clinical value as a marker of stress and metabolic changes in the body is not yet clearly defined.

The role of cortisol in the regulation of metabolic homeostasis is even controversial, while some articles show that it increases in individuals with $\mathrm{MS}^{1,2,23}$, a large study of 726 adults found no significant association between the components of MS and changes in levels of salivary cortisol throughout the day. However, individuals with MS had $16 \%$ lower salivary cortisol than those without this diagnosis 4 .

The dysfunction of the adrenal pituitary hypothalamus axis is associated with obesity and MS and, consequently, $\mathrm{BMI}$; increased abdominal circumference and visceral fat are associated with low levels of salivary cortisol in the morning ${ }^{19}$. 
In this study, the relationship between the components of MS and their association with insulin resistance can be seen in Table 3. Although no significant correlation between insulin resistance measured by HOMA-IR and morning cortisol has been demonstrated, other authors suggest that salivary cortisol tend to increase with high BMI and correlate with hip circumference in men and with systolic pressure in women significantly. Even so, the study concluded that these data do not support a strong relationship between cortisol levels and SM components ${ }^{1}$.

Analyzing the relationship between salivary cortisol and obesity, a study of 82 subjects showed that there was no difference in the level of morning salivary cortisol between non-obese, obese and weight-loss individuals ${ }^{2}$. However, men who lost weight have a lower level than non-obese men; this relationship in women was not observed. The observation that visceral fat loss may reduce hypothalamic-pituitary-adrenal axis activity contrasts with the findings that weight loss associated with restriction of caloric intake increases the activity of the hypothalamic-pituitary axis ${ }^{26}$. From this it can be inferred that fasting and weight loss may increase circulating levels of cortisol, possibly to increase appetite in an attempt to "defend" itself from loss of body mass.

In fact, current literature shows inconsistent relationships between cortisol levels and metabolic parameters. While one study shows a tendency to increase salivary cortisol in higher $\mathrm{BMI}^{1}$, another shows an inverse correlation between morning salivary cortisol levels ${ }^{2}$. In this study, the correlation between cortisol and BMI was not significant, most probably because the sample did not have patients with very high BMI (no patient with $\mathrm{BMI}>40 \mathrm{~kg} / \mathrm{m}^{2}$ ).

Previous studies have reported that individual components of MS and activity of the hypothalamic-pituitary-adrenal axis are related; however, few studies have examined the components individually. Specifically, elevated hip circumference has been associated with high rates of morning cortisol and related to stress reactivity as well as decreasing cortisol variability throughout the day. Evidence suggests that hypertension is associated with morning cortisol levels and/or cortisol stress reactivity. Studies of the BMI association and central adiposity with cortisol have been misleading with some reporting that people with high BMI and adiposity rates have high cortisol under-curves; but others report that people with high BMI and waist circumference have low levels of cortisol at dawn and a decrease in the rate of daily drop in cortisol levels ${ }^{1,4}$.

\section{CONCLUSIONS}

Salivary cortisol in the morning in individuals with chronically elevated glycemia may represent a counter-regulation of the hypothalamic-pituitary-adrenal axis, being important marker and not well investigated till now.

\section{REFERENCES}

1. Abrahan SB, Rubino D, Sinaii N, Ramsey S, Nieman LK. Cortisol, Obesity, and the metabolic: across-sectional study of obese subjects and review of the literature. Obesity. 2013;21(1):105-17.

2. Champaneri $S, X u X$, Carnethon MR, Bertoni AG, Seeman T, DeSantis AS, et al. Diurnal salivary cortisol is associated with body mass index and waist circumference: the multiethnic study of atherosclerosis. Obesity. 2013:21(1):56-63.

3. Collaziol D, Luz C, Dornelles F, Cruz I, Bauer ME. Psycho neuroendocrine correlates of lymphocyte subsets during healthy ageing. Mech Ageing Dev. 2004;125:219-27.

4. De Santis AS, Diez Roux AV, Hajat A, Golden SH, Jenny NS, Sanchez BN, et al. Association of salivary cortisol levels with metabolic syndrome and its components: the multi-ethnic study of atherosclerosis. J Clin Endocrinal Metab. 2011;96(11):3483-92.
5. Duclos M, Gatta B, Corcuff JB, Rachedi M, Pehourcq F, Roger P. Fat distribution in obese women is associated with subtle alterations of the hypothalamic-pituitary-adrenal axis activity and sensitivity to glucocorticoids. Clin endocrinol (Oxf). 2001;55:447-54.

6. Duclos M, Marquez Pereira P, Barat P, Gatta B, Roger P. Increased cortisol bioavailability abdominal obesity, and the metabolic syndrome in obese women. Obes Res. 2005;13:1157-66.

7. Grundy SM, Cleeman J, Daniels SR, Donato KA, Eckel RH, Franklin BA et al. Diagnosis and management of the metabolic syndrome: an American Heart Association/National Heart, Lung, and Blood Institute Scientific Statement. Circulation. 2005;112(17):2735-52.

8. HoltR. TheFoodandAgricultureOrganization/World HealthOrganization expert report on diet, nutrition and prevention of chronic diseases. Diabetes Obes Metab.2003;5(5):354.

9. Huang PL. A comprehensive definition for metabolic syndrome. Dis Model Mech. 2009:2(5-6):231-7.

10. Jeckel CM, Lopes RP, Berleze MC, Luz C, Feix L, Argimon II, et al. Neuroendocrine and immunological correlates of chronic stress in 'strictly healthy' populations. Neuroimunomodulation. 2010;17:9-18.

11. Khalsa DS, Stauth CA. Longevidade do cérebro. $4^{a}$ ed. São Paulo:Objetiva; 1997.Disponível em: http://br.librosintinta.in/11-khalsa-ds\%2C-stauthca-longevidade-do-c\%C3\%A9rebro-4\%C2\%AA-ed-s\%C3\%A3o-pauloobjetiva\%3B-1997-pdf.html.

12. Lohman TG, Roche AF, Martorell R. Anthropometric Standardization Reference Manual. 1988 Champaing: Human Kinetics Books.

13. MargaretC,MoreiraCA.Salivarycortisolontheevaluationofthehypothalamicpituitary-adrenal axis. Arq Bras EndocrinolMetab. 2003;47(4):358-67.

14. Marin O, Darin N, Amemiya T, Anderson B, Jern S, Bjorntorp P. Cortisol secretion in relation to body fat distribution in obese premenopausal women. Metabolism. 1992;41;882-6.

15. NationalCholesterolEducationProgram(NCEPIII)ExpertPanelonDetection, Evaluation, and Treatment of High Blood Cholesterol in Adults (Adults Treatment Panel III). Third report of the National Cholesterol Education Program expert panel on detection, evaluation, and treatment of high blood cholesterol in adults - Adults Treatment Panel III (NCEP-ATP III). Final report. Circulation.2002;106(25):3143-421.

16. National Institutes ofHealth $(\mathrm{NIH})$. The practical guidetotheidentification, evaluation, and treatmentofoverweightandobesityinadults. [capturadoem 2015Mai6].Disponívelem:http://www.nhibi.nih.gov/guidelines/obesity/ prdtge_c.pdf.

17. National Research Council. Diet and Healthy: implications for reducing chronic disease risk. Washington, DC: Nacional Academy Press, 1989.

18. Nolte $E_{1}$ McKee M.Caring for people with chronic conditions, a health system perspective. European Observatoryon health systemsand policies series Open University Press. 2008 [capturado2015 Mai2015];1(primeira publicação):1-290.Disponívelem:http://apsredes.org/site2012/wpcontent/ uploads/2012/03/Caringforpeoplewithchronicconditions.pdf\#page=87

19. Paredes S, Ribeiro L. Cortisol: the villain in metabolic syndrome? Rev Assoc Med Bras. 2014:60(1):80-92

20. PasqualeR,AndrosiB,ArmaniniD, et.al.CortisolandACTH responsetooral dexamethasone and obesity and effects of sex, body fat distribution, and dexamethasoneconcentration:Adose-responsestudy.JClinEndocrinolMetab. 2002;87:166-75

21. Pasquale $R$, Cantobelli $S$, Casimirri $F$, et.al. The hypothalamic, pituitary - adrenal axis in obese woman with different patterns of body fat distribution. J ClinEndocrinolMetab. 1993;77:341-6.

22. Saboya PMHP. Efeito da modificação do estilo de vida nos parâmetros metabólicosenaqualidadedevidadepacientescomsíndromemetabólica [tese].[capturado em 2015Nov 13]. Disponivel em: http://tede2.pucrs. br/tede2/bitstream/tede/1794/1/464326.pdf.

23. Siddiquiab A, Madhub SV, Sharmac SB, Desaid NG. Endocrine stress responses andriskoftype2 diabetes mellitus. Stress. 2015:15(5):498-506.

24. SociedadeBrasileiradeCardiologia/SociedadeBrasileiradeHipertensão/ SociedadeBrasileirade Nefrologia. VIDiretrizesBrasileiras deHipertensão. Arq Bras Cardiol. 2010;95(1 supl.1):1-51.

25. Steptoe A, Kunz-Ebrecht SR, Brydon L, Wardle J. Central adiposity and cortisol responses to waking in middle-aged man and women. Int ObesRelatMetabDisord. 2004;28:1168-73

26. Therrien F, Drapeau V, Lalonde J, Lupien S, Beaulieu S, Doré J, et al. Cortisol response to the Trier Social Stress Test in obese and reduced obese individuals. Biol Psychol. 2010;84:325-9.

27. Willmore JH, Costill DL. Fisiologia do esporte e do exercício. $2^{\mathrm{a}}$ ed. São Paulo: Manole; 2005. Disponivel em: http://br.librosintinta.in/fisiologiado-esporte-wilmore-pdf.html. 